\title{
Opinion of Farm Women toward Components of TV Programmes
}

\author{
Neha Goswami* and Asha Godawat \\ Department of Extension Education and Communication Management, Maharana Pratap \\ University of Agriculture and Technology, Udaipur, (Rajasthan), India \\ *Corresponding author
}

\section{A B S T R A C T}

\begin{tabular}{|l|}
\hline Ke y w or d s \\
Opinion, Farm \\
women, TV \\
programmes, Farm, \\
Home and \\
Components
\end{tabular}

\section{Introduction}

Globally, today the life of man and the society in which he lives has witnessed media and communication explosion. People are information hungry and needs timely and updated information for their development. Mass media channels play a crucial role for rapid dissemination of any new information, innovation and technology to a large segment in a fraction of time particularly people living in remote areas especially farming community. For that purpose television has given new choice to the farming community for watching the different agricultural programmes on different channels. Farmers choose the best way for keeping up to date about different information of agriculture. Apart from the farmers, farm women also indulge in agricultural activities. She is the central figure in the family influencing and serving the social, economic and cultural needs and standards of the family. Access to communication media prepares women for improving their communication and mediation skills to strengthen their capacity to contact and mediate with external world. Today in the era of science and technology, the Indian farm women are required to make many decisions regarding the acceptance of new technology in the area of farm and home, but because of lack of knowledge and 
illiteracy, she is not able to take wise decision to use new technology. Farm women should be fully aware of the latest agricultural technologies so as to achieve faster development in agriculture. The transfer of technology approach which mainly includes mass media is not paying much attention towards dissemination of adequate and timely agricultural information to the farm women (Santra and Kundu, 2001). With the objective to impart latest \& useful agricultural and home making information to rural masses various farm and home related programmes telecast on different channels. The success of programme depends on awareness, preference and opinion of the people for whom the programme is planned. So with this study opinion of the farm women should be analyzed critically.

\section{Materials and Methods}

The present investigation was carried out in one rural panchayat samiti of Udaipur district i.e. Badgaon panchayat samiti which was selected randomly. From the selected panchayat samiti four villages namely Iswal, Kavita, Lausing and Kadiya having approximately $20-25 \mathrm{~km}$ distance from district headquarter were selected purposively. For the selection of sample a list of farm families having cable connection was prepared separately for each village with the help of local cable operators. From the list 25 farm women from each village who were the viewers of TV programmes and willing to respond were selected to form a total sample of 100 respondents. The data were collected personally with the help of an interview schedule. The data so obtained were tabulated and analyzed by using the simple statistical techniques of frequency, average, percentage and Mean weighted scores.

Mean weighted score (MWS): To measure the overall opinion of the respondents mean weighted scores were calculated. For this a rating scale was developed by the researcher having 3 point continuum "strongly agree" "agree" and "disagree" with scores 3, 2 and 1 for favourable statements and 1,2 and 3 for unfavourable statements. For each statement the frequency of respondents under each rating was calculated, multiplied by assigned scores and added. The resulting sum of each statement was divided by total number of respondents (100).

\begin{tabular}{|l|r|}
\hline S. No. & Categories and MWS range \\
\hline 1. & Most Favourable $(2-3)$ \\
\hline 2. & Favourable $(1-1.99)$ \\
\hline 3. & Unfavourable $(0-0.99)$ \\
\hline
\end{tabular}

\section{Results and Discussion}

Data in the table 1 reflected that more than half of the respondents were strongly agree that programmes are informative and according to their interest and reported that programmes telecast through selected channels provide information on nutrition, health \& hygiene, environmental sanitation, consumer awareness and government programmes \& policies. Regarding relevancy, accuracy and reliability of the programme data in the table reflect that the majority of the respondents were not in the favour of inaccuracy of message $(77 \%)$, irrelevancy $(70 \%)$ and unreliable information $(60 \%)$ in the programme. They perceived that the information is helpful in their day to day activities.

A perusal of the table also indicate that more than half $(50 \%)$ of respondents were agree that information is applicable \& phone-in-live programme is also not properly maintained under the programme. However, 42 per cent respondents perceived that phone-in-live programme is helpful in clarifying their doubts by satisfying their queries on toll- free number and 36 per cent respondents opined 
that information about local market is provided under Krishi Darshan programme of DD Rajasthan channel.

Less than half of the respondents were strongly agree that information about appropriate farm \& homestead technologies, advertisement makes them aware and repetition of the programme at weekend is helpful in getting the information. On contrary, nearly 27 per cent of the respondents were disagree that technologies are cost effective and inclined that information was quite difficult to understand $\&$ expensive so that it is not easily adopted by them and 30 per cent respondents were not in favour that advertisement make them aware about new technologies. The reason for such findings might be that generally people switched to different channel during advertisement or doing other work. Nearly an equal number of respondents were strongly agree, agree and disagree that messages are clear and titles of the programmes are attractive.

Findings of the study are in line with the results of Deshmukh and Wattamwar (2010) and Devendrapp (2014) revealed that majority of the respondents perceived that farm TV programmes are useful, effective, motivating, clear and suitable for its adoption.

Table.1 Opinion of the respondents towards content of the TV programmes $n=100$

\begin{tabular}{|c|c|c|c|c|c|}
\hline S. No. & Components & $\begin{array}{l}\text { SA } \\
\mathbf{f} / \%\end{array}$ & $\underset{\mathbf{f} / \%}{\mathbf{A}}$ & $\begin{array}{l}\text { DA } \\
\mathbf{f} / \%\end{array}$ & MWS \\
\hline \multirow[t]{16}{*}{1.} & \multicolumn{5}{|l|}{ Content } \\
\hline & a. Programmes are informative & 56 & 30 & 14 & 2.42 \\
\hline & $\begin{array}{l}\text { b. Content of programme is according to } \\
\text { viewer's interest }\end{array}$ & 52 & 34 & 14 & 2.38 \\
\hline & c. Information are not relevant & 0 & 30 & 70 & 2.70 \\
\hline & d. There is clarity in the messages & 30 & 34 & 36 & 1.94 \\
\hline & e. Information has practicability & 30 & 58 & 12 & 2.18 \\
\hline & f. Lack of accuracy in the messages & 1 & 21 & 77 & 2.75 \\
\hline & g. Information is according to the season & 24 & 52 & 24 & 2.0 \\
\hline & h. Information is not reliable & 15 & 25 & 60 & 2.45 \\
\hline & i. Title of the programme is attractive & 34 & 30 & 36 & 1.98 \\
\hline & $\begin{array}{l}\text { j. There is lack of information about govt. } \\
\text { programme and policies }\end{array}$ & 12 & 68 & 20 & 2.08 \\
\hline & $\begin{array}{l}\text { k. Advertisement make aware about new } \\
\text { technologies \& products of home and } \\
\text { agriculture }\end{array}$ & 45 & 25 & 30 & 2.15 \\
\hline & $\begin{array}{l}\text { 1. Programme on phone-in-live is not properly } \\
\text { maintained }\end{array}$ & 0 & 58 & 42 & 2.42 \\
\hline & $\begin{array}{l}\text { m. Local market information is not given in the } \\
\text { programme }\end{array}$ & 12 & 52 & 36 & 2.24 \\
\hline & $\begin{array}{l}\text { n. Repetition of important programmes at } \\
\text { weekends }\end{array}$ & 48 & 30 & 22 & 2.26 \\
\hline & $\begin{array}{l}\text { o. Technologies are cost effective and can be } \\
\text { easily adoptable }\end{array}$ & 42 & 31 & 27 & 2.15 \\
\hline
\end{tabular}


Table. 2 Opinion of the respondents towards content utility of the TV programmes $n=100$

\begin{tabular}{|c|c|c|c|c|c|}
\hline S. No. & Components & $\begin{array}{l}\text { SA } \\
\mathbf{f} / \%\end{array}$ & $\begin{array}{c}\mathbf{A} \\
\mathbf{f} / \%\end{array}$ & $\begin{array}{l}\text { DA } \\
\text { f/\% }\end{array}$ & MWS \\
\hline \multirow[t]{12}{*}{1.} & \multicolumn{5}{|l|}{ Content Utility } \\
\hline & $\begin{array}{l}\text { a. Helps to know about balance diet and } \\
\text { new recipes }\end{array}$ & 74 & 26 & 0 & 2.74 \\
\hline & b. Helps in improving the cooking methods & 64 & 35 & 0 & 2.62 \\
\hline & $\begin{array}{l}\text { It gives information about nutrition, } \\
\text { health \& hygiene and environmental } \\
\text { sanitation }\end{array}$ & 48 & 30 & 22 & 2.26 \\
\hline & d. Success stories are motivational & 44 & 31 & 25 & 2.19 \\
\hline & $\begin{array}{l}\text { e. Provides information about livestock } \\
\text { management }\end{array}$ & 41 & 44 & 15 & 2.26 \\
\hline & $\begin{array}{l}\text { f. It provides information about improved } \\
\text { farm and home related practices }\end{array}$ & 31 & 45 & 24 & 2.07 \\
\hline & $\begin{array}{l}\text { g. Helped to know about current affairs and } \\
\text { news }\end{array}$ & 20 & 22 & 58 & 1.62 \\
\hline & $\begin{array}{l}\text { h. Gives information about initiatives of } \\
\text { government for rural development }\end{array}$ & 18 & 25 & 57 & 1.61 \\
\hline & $\begin{array}{l}\text { i. Helped in getting to know rights for } \\
\text { women }\end{array}$ & 10 & 21 & 69 & 1.41 \\
\hline & $\begin{array}{l}\text { j. It makes aware about importance of } \\
\text { organic foods }\end{array}$ & 4 & 20 & 76 & 1.28 \\
\hline & k. Consumer awareness & 2 & 27 & 71 & 1.31 \\
\hline
\end{tabular}

Table.3 Opinion of the respondents towards language, time \& duration of the TV programmes $\mathrm{n}=100$

\begin{tabular}{|c|c|c|c|c|c|}
\hline S. NO. & Components & $\begin{array}{l}\text { SA } \\
\mathbf{f} / \%\end{array}$ & $\mathbf{A}$ & $\begin{array}{l}\text { DA } \\
\mathbf{f} / \%\end{array}$ & MWS \\
\hline \multirow[t]{4}{*}{1.} & \multicolumn{5}{|l|}{ Language } \\
\hline & a. Language is simple and understandable & 25 & 42 & 33 & 1.92 \\
\hline & b. Sentences are short & 31 & 35 & 34 & 1.97 \\
\hline & $\begin{array}{l}\text { c. Technical words used are not easy to } \\
\text { understand }\end{array}$ & 82 & 18 & 0 & 1.18 \\
\hline \multirow[t]{6}{*}{2.} & \multicolumn{5}{|l|}{ Time and duration } \\
\hline & a. Morning telecast time is not suitable & 64 & 32 & 4 & 1.40 \\
\hline & b. Evening telecast is suitable & 59 & 30 & 11 & 2.48 \\
\hline & $\begin{array}{l}\text { c. Schedule of the programme is } \\
\text { intimated well in advance }\end{array}$ & 32 & 35 & 33 & 1.99 \\
\hline & $\begin{array}{l}\text { d. Duration of farm programmes is } \\
\text { appropriate }\end{array}$ & 18 & 60 & 22 & 1.96 \\
\hline & $\begin{array}{l}\text { e. Duration of home related programme is } \\
\text { not sufficient to cover the programme }\end{array}$ & 32 & 35 & 33 & 2.01 \\
\hline
\end{tabular}


Table.4 Opinion of the respondents toward mode of presentation of the TV programmes $n=100$

\begin{tabular}{|c|c|c|c|c|c|}
\hline S. NO. & Components & $\begin{array}{l}\text { SA } \\
\mathbf{f} / \%\end{array}$ & $\begin{array}{c}\mathbf{A} \\
\mathbf{f} / \%\end{array}$ & $\begin{array}{l}\text { DA } \\
\mathbf{f} / \%\end{array}$ & MWS \\
\hline \multirow[t]{7}{*}{1.} & \multicolumn{5}{|l|}{ Mode of presentation } \\
\hline & $\begin{array}{l}\text { a. Appropriate selection of mode of } \\
\text { presentation }\end{array}$ & 31 & 32 & 37 & 1.94 \\
\hline & $\begin{array}{l}\text { b. There is combination of different methods } \\
\text { of presentation in the programme }\end{array}$ & 20 & 42 & 38 & 1.82 \\
\hline & c. Audio and visuals are well synchronized & 34 & 32 & 34 & 2 \\
\hline & $\begin{array}{l}\text { d. Toll free phone-in-facilities helps in } \\
\text { clarifying the doubts }\end{array}$ & 18 & 60 & 22 & 1.96 \\
\hline & e. Traditional media are used & 0 & 0 & 100 & 1 \\
\hline & f. Background music distract the attention & 0 & 0 & 100 & 1 \\
\hline
\end{tabular}

Table.5 Overall opinion of the respondents toward various components of the TV programmes

\begin{tabular}{|c|c|c|}
\hline S.no. & $\begin{array}{c}\text { Categories and MWS scores } \\
\text { range }\end{array}$ & $\mathbf{f} / \%$ \\
\hline 1. & Most favourable $(2.35-3)$ & 51 \\
\hline 2. & Favourable $(1.68-2.34)$ & 39 \\
\hline 3. & Unfavourable $(1-1.67)$ & 10 \\
\hline
\end{tabular}

Fig.1 Overall opinion of the respondents toward various components of TV programmes

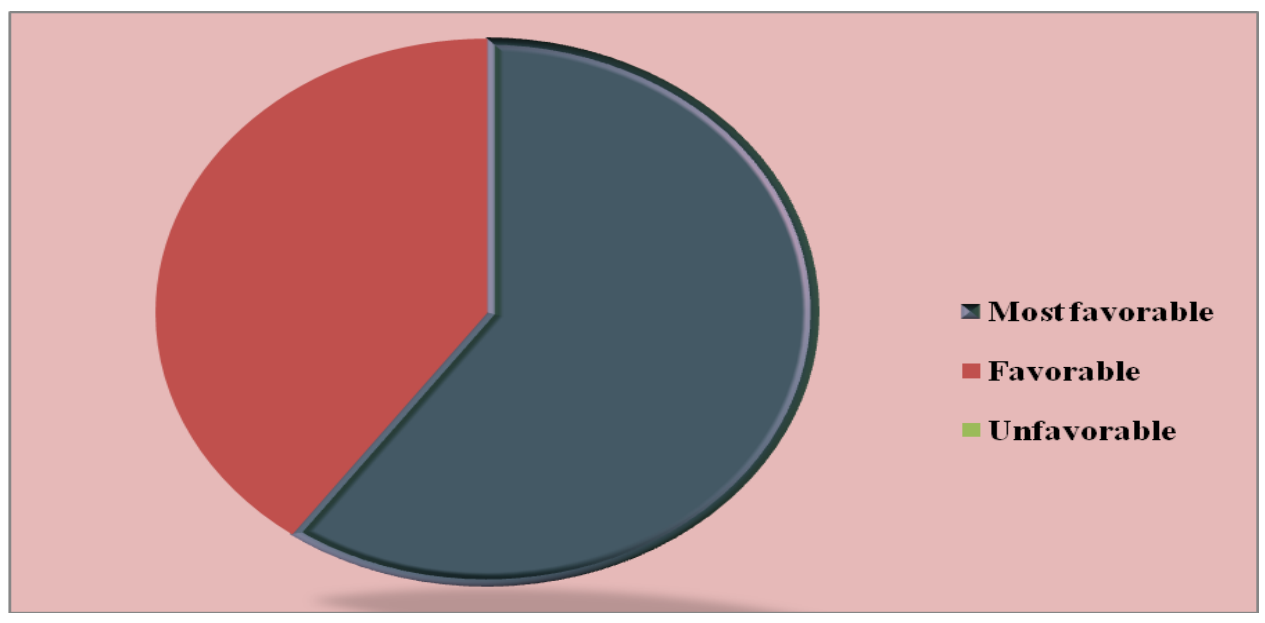

An overview of MWS with range 1.28-1.62 reflects that respondents had favorable opinion towards the information about importance of organic foods, current affairs, government initiatives, women rights and consumer awareness are useful to them. It is also appreciate to note that respondents had most favourable opinion towards the utility of content of farm \& home related TV programmes as indicated by MWS 2.13-2.89. During the informal discussion with the respondents it has been observed that the farm women were not aware about these programmes and they were mostly viewed the entertainment programmes on Colors, Zee TV and Star Plus channels. 
Table 3 indicates that majority of the respondents had favourable opinion towards language, time and duration of TV programmes as reflected by MWSs ranging from 1.92-2.01. An in-depth analysis of the table indicate that $35-42$ per cent respondents agreed that language of the programme content is simple, easy to understand and sentences are short that helps in better understanding of the information. Apart from that one third of the respondents perceived that language is difficult to understand \& sentences are long and opined that programmes should be telecast in regional language "Mewari". Data also exhibit that $82 \%$ perceived that most of the time technical words in the programmes are used that hinders their understanding.

With regard to information pertaining to time and duration of TV programmes data state that more than 50 per cent respondents were strongly in favour that programmes telecast in the evening are suitable for them and reported that they are free from the farm and household work, 30 minutes duration of home related programmes (Rasoise, Kalyani and Chat par bagwani) are appropriate to cover the content of the programme and one third of the respondents agreed that information about the schedule programme is intimated well in advance.

The result of study is supported by the findings of the study conducted by Nazir \& Hassan (2011), Saibaba et al., (2011) and Lal (2012), reported that majority of the respondents $(80 \%)$ opined that language of farm TV programme is suitable and programmes telecast during 6:00-8:00 pm is able to catch the interest of the viewers rather than programmes telecast on other timings.

Data in the table 4 reveal that nearly one third of the respondents were strongly agree, agree and disagree with the programme formats and synchronization of audio \& visuals in the programme and nearly 40 per cent respondents perceived that there is lack of combination of different methods. With regard to toll free phone-in facility, use of traditional media and background music majority of the respondents agreed that it helps in clarifying their doubts and all the respondents were not in favour of use of traditional media and background music as it distract the attention. From the finding it could be concluded that respondents were in the favor of mode of presentation of programmmes telecasted on selected channels.

\section{Overall opinion of farm women towards various components of the farm \& home related TV programmes}

On the basis of overall opinion of respondents in various components of farm \& home related TV programmes, they were categorized into three equidistance categories as most favourable, favourable and unfavourable. The results are presented in Table 5.

Visualization of Table 5 and Figure 1 show that 51 per cent were in the category of most favourable opinion, 39 per cent were in the category of favourable opinion and only 10 per cent respondents had unfavourable opinion towards different components of TV programmes.

From the findings it can be concluded that farm women had favourable opinion towards the various components of TV programmes as content, content utility, time, duration and mode of presentation. Programme producers make full efforts to produce that programmes which disseminate useful, authentic and economic information to the viewer's. As farm women are busy in doing their farm and household works so the important message should be telecast at evening time when almost all the work came to an end. Farm 
women have been long accorded as invisible workers in Agriculture, and their contribution for agricultural development is tremendous. Hence, organizing and promoting effective use of media forums in radio, television and print media would play a vital role in enlightening farm women for agricultural development. Thus, there is a need to make about the farm and home related programmes telecast on different channels.

\section{References}

Deshmukh, P.R. and Wattamwar, V.T. 2010. Effectiveness of farm programme Amachi Mati Amachi Mansa perceived by televiewing farmers. Journal of Agricultural Extension Management. 11:22-29.

Devendrappa, S. 2014. Farm telecast on Kannada channels and their impact on farmers. Ph.D. (Mass Communication and Journalism) thesis (unpublished),
Karnatak University, Dharwad.

Lal, B. 2012. A study to assess the awareness of the farmers about the farm TV programmes. Indian Journal of Research. 6:189-191.

Nazir, Md. R. and Hassan, Md. S. B. 2011. The role of television in the enhancement of farmer's agricultural knowledge. African Journal of Agricultural Research. 6(4): 931-936.

Saibaba, A., Mohan, R.M., Kumar, D.A. and Prasanna, K. T. 2011. Television for the promotion of health and nutrition information- A study of Indian urban viewers. Nutrition and Dietetic. 68(3):65-69.

Santra, S.K. and Kundu, R. 2001. Women's empowerment for sustainable agriculture development. Manage Extension Research Review. 2:131135.

\section{How to cite this article:}

Neha Goswami and Asha Godawat. 2020. Opinion of Farm Women toward Components of TV Programmes. Int.J.Curr.Microbiol.App.Sci. 9(12): 2156-2162.

doi: https://doi.org/10.20546/ijcmas.2020.912.254 